\title{
Correction to: Nonparametric series density estimation and testing
}

\author{
Patrick Marsh ${ }^{1}$
}

Published online: 11 September 2018

(c) The Author(s) 2018

\section{Correction to: Stat Methods Appl https://doi.org/10.1007/s10260-018-00432-y}

The article 'Nonparametric series density estimation and testing', written by Patrick Marsh, was originally published electronically on the publisher's internet portal (currently SpringerLink) on 1 August 2018 with an incorrect copyright line. As the article was due to be published with open choice, the copyright of the article changed on 28 August 2018 to (C) The Author(s) 2018 and the article is forthwith distributed under the terms of the Creative Commons Attribution 4.0 International License (http://creativec ommons.org/licenses/by/4.0), which permits use, duplication, adaptation, distribution and reproduction in any medium or format, as long as you give appropriate credit to the original author(s) and the source, provide a link to the Creative Commons license and indicate if changes were made. The original article has been corrected.

Open Access This article is distributed under the terms of the Creative Commons Attribution 4.0 International License (http://creativecommons.org/licenses/by/4.0/), which permits unrestricted use, distribution, and reproduction in any medium, provided you give appropriate credit to the original author(s) and the source, provide a link to the Creative Commons license, and indicate if changes were made.

The original article can be found online at https://doi.org/10.1007/s10260-018-00432-y.

Patrick Marsh

Patrick.Marsh@nottingham.ac.uk

1 School of Economics, University of Nottingham, Nottingham, UK 